\title{
COVID-19 Pandemic: Its Impact on Learning Motivation (The Fluctuation During Three Different Phases)
}

\author{
Lina Natalya ${ }^{1 *}$, Steven Victoria Halim² ${ }^{2}$ iD \\ ${ }^{1}$ Faculty of Psychology, Universitas Surabaya, Surabaya, Indonesia \\ ${ }^{2}$ Centre of Medicine Information and Pharmaceutical Care, Universitas Surabaya, Surabaya, Indonesia \\ *Corresponding author: lina.metabus@gmail.com
}

\section{Abstract}

Education is a critical component that cannot be separated from an individual's life. One of many important factors that could support, encourage, and give zeal in the learning process is motivation. The COVID-19 pandemic nowadays indirectly triggers a rapid and drastic change in the learning process, one of them being lecture that must be held online. This repeated crosssectional research aimed to give a description regarding the fluctuation of students' academic motivation level before, in the beginning, and until one-year after online learning. The data used in this study are primary and secondary data which are collected gradually and analyzed using Summary Independent Sample T-Test. The result of this research showed no significant differences in academic motivation before COVID-19 and during the early days of Learning From Home $\left(\mu_{\text {before }}=4.777\right.$; $\mu_{\text {beginning }}=4.808$; sig $=0.432$ ), nevertheless, a significant decrease is observable one year after the online learning $\left(\mu_{\text {now }}=\right.$ 4.345; sig $_{\text {before-now }}=<0.001$; sig beginning-now $=<0.001$ ). The decrease in students' academic motivation is certainly a crucial problem that is prioritized to be resolved. Hence, lecturers need to adapt with this change and create learning innovation in order to trigger students' learning motivation.

Keywords: Academic Motivation, Online Learning, Learning From Home, Summary Independent Sample T-Test

$\begin{array}{lll}\text { History: } & & \text { Publisher: Undiksha Press } \\ \text { Received } & \text { : July } 21,2021 & \text { Licensed: This work is licensed under } \\ \text { Revised } & \text { : July } 25,2021 & \text { a Creative Commons Attribution 3.0 License } \\ \text { Accepted } & \text { : August 29, 2021 } & \text { CC C) OP }\end{array}$

\section{INTRODUCTION}

Education is an important process, and its attribute is inherent in human life. An excellent educational quality can only be obtained when it supported by qualified lecturers, high motivation, self-discipline, as well as family's socioeconomic circumstances, and past learning experiences. Using the Decision Tree algorithm, Sabna and Muhardi (2016) research discovered that motivation is not the only factor that determines achievement and success nowadays. Sabna and Muhardi (2016) showed that achievement is also determined by past learning experiences and family's socioeconomic circumstances, although those individual factors do not necessarily affect one's motivation (Sabna \& Muhardi, 2016). Motivation and learning are two inseparable aspects and they also influence one another. For instance, if someone wants to learn, they need motivation inside himself/herself. Motivation is the root of every human's behaviour, with no exception of the student's learning behaviour (Guay et al., 2010). Motivation is an important thing to support and encourage someone to achieve their goal (Santrock, 2017). Broussard and Garrison, (2004) emphasized that motivation is an attribute that shape one's desire to do a particular activity. Motivation is closely related to power, drive, and perseverance felt by someone. In the academic context, that drive will be closely related to learning activities. Without motivation, learning process (in general) and doing a particular task (in specific) will be exceedingly difficult to do.

By this time, there are several studies completed in order to describe student's motivation level. In addition, a research by Anas and Aryani (2014) indicated that $63.84 \%$ students from Fakultas Ilmu Pendidikan Universitas Negeri Makassar had high motivation in attending lectures. Approximately 40.48-59.59\% among them expect to be seen as diligent and active students. However, the result of qualitative analysis of this research found that most of 
the students told that they are bored and oftentimes not attending the lectures. As many as $55.90 \%$ students assumed that the class attendance was associated with an " $A$ " grade at the end of the semester. Accomplish satisfying achievements are the source of powerful drive for students to undergo their learning process in college diligently (Anas \& Aryani, 2014).

In consonance with Self-Determination Theory (SDT) developed by Deci and Ryan, motivation is continuously consisting of intrinsic motivation, extrinsic motivation, and amotivation (Hazrati-Viari, Rad, \& Torabi, 2012). In line with that theory, Adiputra and Mujiyati (2017) stated that motivation occurs as the consequences of the internal drive as well as the external stimulus, such as surrounding environment. Waqar, Shafiq, and Hasan, (2016) revealed that each intrinsic motivation, extrinsic motivation, and amotivation has its own influence on an individual. Three components of motivation are contributing to how an individual respond when dealing with his or her experiences, specifically in college experience up until it gives an impact on work performance and achievement. Several studies proved that intrinsic motivation could increase along with positive feedbacks that are often received by students from the authorized figures (Waqar, Shafiq, \& Hasan, 2016). This thing will indirectly grow one's self-confidence, since according to Hensley (2014), motivation has two kinds of belief one of which is self-efficacy. Self-efficacy would enable the college students to assess their ability in finishing academic tasks as their responsibility. The higher the self-efficacy owned by a student, the higher the motivation to finish college tasks and responsibilities, and vice versa.

A number of published researches affirmed a few factors that affect learning motivation. Sabna and Muhardi (2016) along with Slameto (2015) showed that one of the many factors that influence learning motivation is environment, including local communities as well as family's environment. Physical and social factors could also directly or indirectly influence college students' motivation. Moreover, as reported by Uno (2014), the existence of hope and future goals could also contribute in developing college students' drive to study. Having a clear future goal would produce motivation for college students to achieve it, which leads them to be motivated in learning well.

One of the many external environment factors that can indirectly influence learning motivation is COVID-19. As it is known, since mid-2020, COVID-19 pandemic has given significant influence on all sectors, with no exceptions on educational sector. All learning activities that were usually carried out face-to-face, had to be done online at home. This rapid change in the learning process, would certainly impacts on college students. A study by Wang et al., (2020) emphasized that the emergence of COVID-19 pandemic increase anxiety disorder, stress, and even depression. Research by Odriozola-González, Planchuelo-Gómez, Irurtia, and de Luis-García (2020) on the college students in Spain showed similar result. Despite the ravage that has been caused by COVID-19 for the past year, Browning and colleague (2021) showed that the main problem for college students nowadays is not loneliness, fear or even anger nor disappointments, but more on the low-level motivation. The result of this study also explained that COVID-19 not only changes student's psychological conditions, but also transforms the students' learning experiences (Browning et al., 2021).

According to the previous studies, the COVID-19 pandemic affect psychological condition of the society, including college students. One of the negative impact of COVID-19 in psychological aspect, especially related to education were a decrease students' motivation, which influenced quality of learning process, subsequently led to the declining academic achievement. Those realities are indirectly describing the domino effects of COVID-19 in education. This research is a first step to explore the impact of COVID-19 on students' learning motivation from three different phases, that were before the COVID-19 pandemic, in the beginning of COVID-19 pandemic, and one year after Learning From Home as the outcome of COVID-19 pandemic. This research is important to help students and lecturers to get the real 
picture of academic motivation and create inovation in learning process to overcome the problem.

\section{METHODS}

This research was a quantitative survey with a repeated cross-sectional design. This study repeated across time and involved different participants with similar characteristic. The purpose of this study was to describe the fluctuative changes in learning motivation level of college students before, in the beginning, and one-year after Learning From Home (LFH) caused by COVID-19. This research consists of 3 phases that were done in different period of time. The first phase was done on October 2019 with the purpose of analyzing the students' academic motivation level before the COVID-19 pandemic. The data that was used for this phase was a secondary data from the researchers' database. The sampling method was accidental sampling in all active college students in Surabaya. The study involved 539 college students. Majority of participant in this phase were female $(71.6 \%)$, and the rest were male (28.4\%). Participant in this study distributed proportionally from class of 2016 to class of 2019 (2016: 33.7\%, 2017: 24.4\%, 2018: 28.1\%, 2019: 13.8\%) with no specification in faculty. All active college students from university in Surabaya were eligible as the research subject. Almost $50 \%$ of the subject was from the faculty of Psychology, and not less than $8 \%$ of them from the faculty of Pharmacy.

The second phase was carried out on April 2020 with the purpose of analyzing academic motivation level during the beginning of COVID-19 pandemic in Indonesia. Identical to the first phase, the data were collected from the researchers' database. There were no significant characteristics differences between the first phase and the second phase participants. For the second phase, data were also obtained from active college students across local and private universities in Surabaya using accidental sampling method. This phase involved 536 students with female students as the majority $(72.9 \%)$ and male students $(48.1 \%)$. The students from the faculty of Psychology did not more than $45.0 \%$ and the students from the faculty of Pharmacy reached more than $10.0 \%$ of its total. The third phase was performed on March 2021 in order to analyze the academic motivation one year after the COVID-19 pandemic that has affected numerous aspects in Indonesia, including education. Unlike the first and the second phase, the data used for this last phase is a primary data. Purposive random sampling was used in this phase. Faculty of Psychology and Pharmacy was selected in this phase because of this two faculty have a diverse in learning process. A total of 785 college students involved in this phase which consist of $17.2 \%$ male, $81.1 \%$ female, and $1.7 \%$ choose to unrevealed their gender. According to the faculty, there were 46.5\% Pharmacy students and 53.5\% Psychology students from universities in Surabaya. All the participants in this phase applied Learning From Home (LFH) since March 2020.

\section{Measurement}

The academic motivation in three phases of this study was measured by using Academic Motivation Scale (AMS) by Vallerand, Pelletier, Blais, Brière, Senécal, and Vallières in 1992, which is composed of three motivation dimensions, namely: intrinsic motivation, extrinsic motivation, and amotivation. Each dimension consist of three sub-dimensions, except amotivation. Academic Motivation Scale (AMS) was one of the several psychological measurements developed by Vallerand et al., (1992) to measure academic motivation multidimensionally (Guay, Morin, Litalien, Valois, \& Vallerand, 2015). As a multidimensional motivation scale, AMS also has 7 sub-dimensions.

The first dimension that is measured in AMS based on Self-Determination Theory (SDT) is intrinsic motivation. According to Ryan and Deci (2000), intrinsic motivation is a drive experienced by an individual to do something happily and satisfied with it. This 
dimension consist of three sub-dimensions, which are Intrinsic Motivation to Know (IMTK), Intrinsic Motivation to Accomplish Things (IMTA), and Intrinsic Motivation to Experience Stimulation (IMES). Intrinsic Motivation to Know (IMTK) can be defined as feelings of delight and satisfaction felt by an individual after learning and exploring something new, while IMTA is feelings of delight and satisfaction felt by an individual after successfully overcoming, finishing, and even creating new things. Last, IMES can be described as feelings of excitement and enjoyment felt by an individual with their activities. That individual would feel happiness and satisfaction in doing particular activities despite not knowing the end results.

The second dimension of AMS is extrinsic motivation. In contrast with intrinsic motivation, Ryan and Deci (2017) defined extrinsic motivation as a drive for someone to behave in order to receive positive consequences or reward from others. There are also three sub-dimensions to describe extrinsic motivation, which are External Regulation (EMER), Introjected Regulation (EMIN), and Identified Regulation (EMID). External Regulation (EMER) can be defined as activities that are not self-determined but set by the rules that are previously agreed by other people and/or by circumstances. This motivation appears in order to receive rewards or avoid punishments. Whereas EMIN is activities that are mostly internalized inside oneself although not fully coherent (connected and affected) with one's life aspects. Despite the existence of internal drive, the behaviours tend to be formed by external causality. Last, EMID can be described as activities that are chosen consciously and independently due to the importance of the activities despite the disinterest.

The third dimension of AMS is amotivation. Amotivation is the lowest autonomous form of motivation (Cokley, 2015). This is resulted from the low intentionality driven by intrinsic as well as extrinsic motivation. Guay et al., (2015) stated that someone who experienced an amotivation does not have the competency, which led Deci and Ryan (in Vallerand et al., 1992) to reveal that someone with high level of amotivation is unable to feel the impact of their labour. Academic Motivation Scale constructed by Vallerand et. al. (1992) was validated into Indonesian Language version by Natalya and Purwanto in 2018. As it was reported in the research, AMS-Versi Bahasa Indonesia was a valid and reliable scale due to the alpha cronbach value that was ranging between $0.746-0.898$ and its CITC value that was ranging between $0.467-0.728$. However, the AMS used in this research was the AMS Bahasa Indonesia - Versi Singkat that was developed by Natalya (2018) with the details Tabel 1.

Table 1. Specification Table for AMS Bahasa Indonesia - Versi Singkat

\begin{tabular}{lcc}
\hline \multicolumn{1}{c}{ Aspects } & Item number & Total \\
\hline Intrinsic Motivation (IM) & & \\
1. Intrinsic Motivation to Know & 1,8 & 2 \\
2. Intrinsic Motivation to Accomplish Things & $5,11,14$ & 3 \\
3. Intrinsic Motivation to Experience Stimulation & 3,9 & 2 \\
Extrinsic Motivation (EM) & & \\
4. External & $7,10,12$ & 3 \\
5. Introjected & 6,15 & 2 \\
6. Identified Regulation & 2 & 1 \\
Amotivation (AM) & 4,13 & 2 \\
\hline
\end{tabular}

As stated in the research by Natalya (2018), AMS Bahasa Indonesia - Versi Singkat had its alpha cronbach ranging between 0.729 - 0.876 and its CITC ranging between 0.466 0.719. Those values proved that AMS Bahasa Indonesia - Versi Singkat was an accurate and precise measurement of academic motivation level. 


\section{Statistical Analysis}

Internal Consistency According to The Standards for Educational and Psychological Testing (AERA et al, 1999), there were five sources of validity evidence that can be used to evaluate the validity of AMS Bahasa Indonesia - Versi Singkat. The validity evidence used in this research was internal consistency. Azwar (2008) stated that reliability can be used to measure consistency and results' precision of a scale. A scale that has high internal consistency tends to produce similar quality of the results in every usage (Coaley, 2010). Natalya (2016) claimed that measuring internal consistency using alpha coefficient only requires a single trial administration data. As a matter of fact, this is one of the advantages of using alpha coefficient as the validity evidence. Moreover, according to Malhotra, Chan, Malhotra, and Ostbye (2012) alpha coefficient can detect inconsistency accurately in each dimension. Therefore, a dimension and/or a scale is reliable if has an alpha cronbach more than equal to $0.6(\alpha \geq 0.6)$ and all items analyzed has corrected item total correlation value of more than equal to 0.3 $(C I T C \geq 0.3)$ Descriptive Statistics Descriptive statistics is one of many statistical methods used to describe the collected data in research. This method aimed to give a clearer and more understandable information. The data presented as a mean, minimum, maximum, and standard deviation value. The result of descriptive statistics gave a comprehensive depiction of the students' academic motivation level from every phase. Summary Independent Samples T-Test is one of the statistical methods used to examine the mean between two different and unrelated groups (Gerald, 2018; K. Kim, 2015). Before starting the analysis of the two sample groups, it is important to analyse the variance value from each of the groups. The two group can be considered different if the significance value is less than equal to 0.05 ( $\mathrm{sig} \leq 0.05)$. The purpose of this analytical method is to discover the discrepancy between the average value of academic motivation level before, during the early days, and after one year co-existing with COVID-19

\section{RESULTS AND DISCUSSION}

\section{Result}

Aims of this study is to give a complete and clear picture of college students' academic motivation level. This research showed academic motivation level from three different period of time, which are academic motivation before, during the early days, and one year after the application of Learning From Home (LFH) due to COVID-19. Validity and reliability of AMS Bahasa Indonesia-Versi Singkat that used in this study has been examined on every phase of the research (phase one to three). The details of the analysis on each phase were as Table 2.

Table 2. AMS Validity and Reliability Analysis on each Three Research Phases

\begin{tabular}{cccccccccc}
\hline $\begin{array}{c}\text { Dimensio } \\
\text { n / Sub- }\end{array}$ & $\begin{array}{c}\text { Tota } \\
\mathbf{l}\end{array}$ & \multicolumn{2}{c}{ Phase 1 (N: 539) } & \multicolumn{2}{c}{ Phase II (N: 536) } & Phase III (N: 785) & \\
$\begin{array}{c}\text { Dimensio } \\
\text { n }\end{array}$ & $\begin{array}{c}\text { Altem } \\
\text { s }\end{array}$ & $\begin{array}{c}\text { Cronbac } \\
\text { h }\end{array}$ & $\begin{array}{c}\text { Rang } \\
\text { e of } \\
\text { CITC }\end{array}$ & $\begin{array}{c}\text { Alpha } \\
\text { Cronbac } \\
\mathbf{h}\end{array}$ & $\begin{array}{c}\text { Rang } \\
\text { e of } \\
\text { CITC }\end{array}$ & $\begin{array}{c}\text { Alpha } \\
\text { Cronba } \\
\text { ch }\end{array}$ & $\begin{array}{c}\text { Range } \\
\text { of } \\
\text { CITC }\end{array}$ & $\begin{array}{c}\text { Conclus } \\
\text { ion }\end{array}$ \\
\hline IMTK & 2 & 0.747 & 0.597 & 0.785 & 0.649 & 0.699 & 0.537 & Reliable \\
IMTA & 3 & 0.714 & 0.534 & 0.711 & 0.469 & 0.687 & $0.441-$ & Reliable \\
& & & - & & - & & 0.564 & \\
& & & 0.544 & & 0.612 & & & \\
IMES & 2 & 0.790 & 0.660 & 0.728 & 0.573 & 0.710 & 0.550 & Reliable \\
\hline
\end{tabular}




\begin{tabular}{|c|c|c|c|c|c|c|c|c|}
\hline \multirow{2}{*}{$\begin{array}{c}\text { Dimensio } \\
\text { n / Sub- } \\
\text { Dimensio } \\
\text { n }\end{array}$} & \multirow{2}{*}{$\begin{array}{l}\text { Tota } \\
\text { I } \\
\text { item } \\
\text { S }\end{array}$} & \multicolumn{2}{|c|}{ Phase 1 (N: 539) } & \multicolumn{2}{|c|}{ Phase II (N: 536) } & \multicolumn{2}{|c|}{ Phase III (N: 785) } & \multirow[b]{2}{*}{$\begin{array}{c}\text { Conclus } \\
\text { ion }\end{array}$} \\
\hline & & $\begin{array}{c}\text { Alpha } \\
\text { Cronbac } \\
\text { h }\end{array}$ & $\begin{array}{c}\text { Rang } \\
\text { e of } \\
\text { CITC }\end{array}$ & $\begin{array}{c}\text { Alpha } \\
\text { Cronbac } \\
\text { h }\end{array}$ & $\begin{array}{c}\text { Rang } \\
\text { e of } \\
\text { CITC }\end{array}$ & $\begin{array}{c}\text { Alpha } \\
\text { Cronba } \\
\text { ch }\end{array}$ & $\begin{array}{c}\text { Range } \\
\text { of } \\
\text { CITC }\end{array}$ & \\
\hline IM & 7 & 0.866 & $\begin{array}{c}0.535 \\
- \\
0.737\end{array}$ & 0.883 & $\begin{array}{c}0.554 \\
- \\
0.743\end{array}$ & 0.841 & $\begin{array}{c}0.455- \\
0.673\end{array}$ & Reliable \\
\hline EMER & 3 & 0.844 & $\begin{array}{c}0.659 \\
- \\
0.786\end{array}$ & 0.828 & $\begin{array}{c}0.650 \\
- \\
0.715\end{array}$ & 0.811 & $\begin{array}{c}0.624- \\
0.731\end{array}$ & Reliable \\
\hline EMIN & 2 & 0.725 & 0.569 & 0.826 & 0.704 & 0.805 & 0.673 & Reliable \\
\hline EMID & 1 & - & - & - & - & - & - & Reliable \\
\hline EM & 6 & 0.832 & $\begin{array}{c}0.477 \\
- \\
0.709\end{array}$ & 0.833 & $\begin{array}{c}0.454 \\
- \\
0.683\end{array}$ & 0.810 & $\begin{array}{c}0.388 \text { - } \\
0.643\end{array}$ & Reliable \\
\hline AMOT & 2 & 0.719 & 0.563 & 0.781 & 0.643 & 0.620 & 0.429 & Reliable \\
\hline AMS & 15 & 0.889 & $\begin{array}{c}0.305 \\
- \\
0.704\end{array}$ & 0.867 & $\begin{array}{c}0.424 \\
- \\
0.668\end{array}$ & 0.875 & $\begin{array}{c}0.306- \\
0.656\end{array}$ & Reliable \\
\hline
\end{tabular}

Note: IMTK= Intrinsic Motivation to Know; IMTA= Intrinsic Motivation to Accomplish Things; IMES= Intrinsic Motivation to Experienced Stimulation; IM= Intrinsic Motivation; EMER= External Regulation; $\mathrm{EMIN}=$ Introjected Regulation; $\mathrm{EMID}=$ Identified Regulation; $\mathrm{EM}=$ Extrinsic Motivation; $\mathrm{AMOT}=$ Amotivation $; \mathrm{AMS}=$ Academic Motivation Scale $; \mathrm{CITC}=$ Corrected Item - Total Correlation $;$ $\mathrm{N}=$ number of research participants

The analysis showed incredibly good internal consistency among all dimensions and sub-dimension from AMS Bahasa Indonesia - Versi Singkat. All the academic motivation scale dimensions and sub-dimensions in the first, second, and third phase had alpha cronbach value of more than 0.6 , subsequently, and each of the items also had a CITC value of more than 0.3. These results showed that academic motivation scale was a credible, accurate, and precise to measure the students' condition on every research phase (the details can be seen on table 2). After ensuring good internal consistencies on all of the items in AMS Bahasa Indonesia - Versi Singkat, the researchers proceeded on computing the descriptive statistics at Table 3.

The results revealed that the highest academic motivation level on students actually seen in the beginning of COVID-19 pandemic. Furthermore, the minimum of AMS score in second phase was still the highest among first and third phase. This statistically shows that the students' learning motivation was slightly increasing. The intrinsic motivation seemed to have a slight decrease, meanwhile the extrinsic motivation was undergoing an increase. There were certainly many factors and reasons behind the changes in the students' academic motivation. Nonetheless, it is a good finding that the mean value of amotivation was decreased across the research phases. This information had proven that overtime, even while undergoing LFH, the 
students had a better understanding in studying and learning. For detail information as mentioned above, table 4 provide Hypothetic Norm comparison as Table 4.

Table 3. Descriptive Statistics Measurement Results

\begin{tabular}{ccccccccccc}
\hline $\begin{array}{c}\text { Dimens } \\
\text { ion }\end{array}$ & \multicolumn{3}{c}{ Phase I (N: 539) } & \multicolumn{3}{c}{ Phase II (N: 536) } & \multicolumn{3}{c}{ Phase III (N: 785) } \\
& $\begin{array}{c}\text { Mi } \\
\mathbf{n}\end{array}$ & Max & $\begin{array}{c}\text { Mean } \\
\text { (Standard } \\
\text { Deviation) }\end{array}$ & Min & Max & $\begin{array}{c}\text { Mean } \\
\text { (Standard } \\
\text { Deviation) }\end{array}$ & Min & Max & $\begin{array}{c}\text { Mean } \\
\text { (Standard } \\
\text { Deviation) }\end{array}$ \\
\hline AMS & 1.47 & 6.00 & $4.77(0.67)$ & 2.33 & 6.00 & $4.81(0.62)$ & 1.67 & 5.60 & $4.34(0.53)$ \\
IM & 1.00 & 6.00 & $4.70(0.76)$ & 1.00 & 6.00 & $4.67(0.76)$ & 1.29 & 6.00 & $4.51(0.73)$ \\
EM & 1.00 & 6.00 & $4.85(0.82)$ & 1.67 & 6.00 & $4.94(0.77)$ & 1.67 & 6.00 & $4.94(0.78)$ \\
AMOT & 1.00 & 6.00 & $2.17(1.08)$ & 1.00 & 6.00 & $2.13(1.08)$ & 1.00 & 6.00 & $1.98(1.01)$ \\
\hline
\end{tabular}

Note: $\min =$ Minimal; $\max =$ Maximal; $\mathrm{N}=$ Number of research participants

Tabel 4. Hypothetic Norm of Academic Motivation

\begin{tabular}{ccccc}
\hline Category & Range & $\begin{array}{c}\text { F1 } \\
\mathbf{n}(\boldsymbol{\%})\end{array}$ & $\begin{array}{c}\mathbf{F 2} \\
\mathbf{n}(\boldsymbol{\%})\end{array}$ & $\begin{array}{c}\text { F3 } \\
\mathbf{n}(\boldsymbol{\%})\end{array}$ \\
\hline Very low & $\mathrm{X}<1.84$ & $3(0.56)$ & $0(0.00)$ & $1(0.13)$ \\
Low & $1.84 \leq \mathrm{X}<2.67$ & $4(0.74)$ & $2(0.37)$ & $2(0.25)$ \\
Slightly Low & $2.67 \leq \mathrm{X}<3.50$ & $15(2.78)$ & $14(2.61)$ & $44(5.61)$ \\
Slightly High & $3.50 \leq \mathrm{X}<4.33$ & $81(15.03)$ & $90(16.79)$ & $300(38.22)$ \\
High & $4.33 \leq \mathrm{X}<5.16$ & $290(53.80)$ & $265(49.44)$ & $399(50.83)$ \\
Very High & $\mathrm{X} \geq 5.16$ & $146(27.09)$ & $165(30.78)$ & $39(4.97)$ \\
\hline
\end{tabular}

Note: F1 = Frequency in the first phase; F2 = Frequency in the second phase; F3 = Frequency in the third phase; $\mathrm{n}=$ Number of research participants in each phase; $(\%)=$ Percentage score

Result from Hypothetic Norm comparison clearly shown that there was a shift in the academic motivation level from the first phase to the second, as well as the third phase. The majority of the participants still had a high level of motivation, but several students that were previously high in motivation experienced a drastic decrease and category change (from high to slightly high) on the third phase. If compared to the first and second phase, there was a twofold increase on the number of students that were in the slightly low motivation category on the third phase. This comparison table is sufficient to illustrate the shifts in students' academic motivation level, but in order to provide a deeper understanding, the T-Test analysis table is presented as Table 5.

The result of T-test analysis of academic motivation in the beginning of COVID-19 showed no significant difference when compared to before the pandemic. The average level of academic motivation in the beginning of COVID-19 showed a slightly higher score than before COVID-19, which are 4.808 and 4.777 , respectively. This indicates that there was some excitement experienced by the students when they began LFH. However, things were different when compared with the condition after one year of doing online learning. The detailed results are as Table 6. 
Table 5. T-Test Analysis of Academic Motivation Before and in the Beginning of COVID-19

\begin{tabular}{llccc}
\multicolumn{1}{c}{ Note } & & Hartley Test & t & sig \\
\hline $\begin{array}{l}\text { Before COVID } \\
\text { (N: 539) }\end{array}$ & $\mu=4.777$ & & & \\
$\begin{array}{l}\text { Beginning of } \\
\text { COVID }\end{array}$ & $\mu=0.674$ & 0.024 & & 0.432 \\
(N: 536) & $\sigma=0.619$ & (Not homogen) & 0.785 & (No differences) \\
\hline
\end{tabular}

Note: $\mu=$ Mean; $\sigma=$ Standard deviation

Table 6. T-Test Analysis of Academic Motivation Before and in the Beginning of COVID-19 Compared to Present Time

\begin{tabular}{|c|c|c|c|c|}
\hline \multicolumn{2}{|c|}{ Note } & Hartley Test & $\mathbf{t}$ & sig \\
\hline Before COVID & $\mu=4.777$ & \multirow{4}{*}{$\begin{array}{c}0.000 \\
\text { (Not homogen) }\end{array}$} & \multirow{4}{*}{12.467} & \multirow{4}{*}{$\begin{array}{c}<0.001 \\
\text { (Significant } \\
\text { differences) }\end{array}$} \\
\hline$(\mathrm{N}: 539)$ & $\sigma=0.674$ & & & \\
\hline One year after & $u=4.345$ & & & \\
\hline $\begin{array}{l}\text { COVID } \\
(\mathrm{N}: 785)\end{array}$ & $\sigma=0.530$ & & & \\
\hline \multirow{2}{*}{$\begin{array}{l}\text { Beginning of } \\
\text { COVID } \\
(\mathrm{N}: 536)\end{array}$} & $\mu=4.808$ & \multirow{3}{*}{$\begin{array}{c}0.001 \\
\text { (Not homogen) }\end{array}$} & \multirow{3}{*}{14.137} & \multirow{3}{*}{$\begin{array}{c}<0.001 \\
\text { (Significant } \\
\text { differences) }\end{array}$} \\
\hline & $\sigma=0.619$ & & & \\
\hline $\begin{array}{l}\text { One year after } \\
\text { COVID } \\
\text { (N: } 785)\end{array}$ & $\begin{array}{l}\mu=4.345 \\
\sigma=0.530\end{array}$ & & & \\
\hline
\end{tabular}

Note: $\mu=$ mean; $\sigma=$ standard deviation

Result of the T-Test analysis on academic motivation value before and during the early days of COVID-19 showed significant differences when compared with one year after LFH due to pandemic. The mean score of academic motivation one year after COVID-19 (mean = 4.345) was lower when compared with the score before COVID-19 (mean =4.777). A similar result was also shown on the t-test analysis between present moment and early COVID-19, whereas the mean motivation level one year post COVID-19 (mean $=4.345$ ) was lower compared with the early days of COVID-19 (mean $=4.808$ ). According to the t-test analysis, there was a difference in academic motivation level before, in the early days, and after one year existing with COVID-19. Some of the student was experiencing a decrease in academic motivation as much as $1 \mathrm{SD}$.

\section{Discussions}

The COVID-19 pandemic has a major impact on all aspects of life, including education with no exception of higher education in Indonesia. Based on the result analysis, it was known that there was a slight increase of motivation level on the early days of Learning From Home (LFH). However, the increase was not significant. Even though the academic motivation was increase in the early days of the pandemic, the decrease of academic motivation one year after LFH had given a significant impact on the students. Indeed, COVID-19 pandemic has immediately happened and shocked numerous people. It also gives a negative impact on the learning process to almost all students in Indonesia. The policymakers have to adapt with this 
condition and change the learning process from the traditional learning method to an all-digital learning process. However, the negative impact of digital or online learning process can't be underestimated and had not been carefully thought of by policymakers. The traditional faceto-face learning process that had previously been perceived as a bored process by most of the students, nowadays turned out to be something missed. A lot of students are longing to visit their campus and attend the class like before the pandemic because of they lack of learning motivation when they just learned in front of their computer screen.

Based on the result of this research, academic motivation level change through the three phase of the study. The mean score of academic motivation (AMS) increase from 4.77 (phase 1) to 4.81 (phase 2) and decrease into 4.34 in the phase 3 . This findings were in congruence with a research by Tan (2021) that showed motivation level increase in the early period of COVID-19. An increase of academic motivation in the early COVID-19 because of students feel happy, fun, free and any other positive emotion. They have a new learning experience by not come to campus to attending the class. The increase of academic motivation score from phase 1 to 2 not significant. However, the academic motivation decreases in phase 3. In fact, precisely academic motivation at phase 3 was the lowest score compared with two other phase. The decrease in academic motivation detected in this research was possible due to the monotone learning method. Kim and Gurvitch (2020) stated that COVID-19 pandemic has changed the society's lifestyle including communication and learning skills. It should be acknowledged that the existence of COVID-19 greatly accelerates educational system at every level. Some of published studies emphasized that online learning can decrease the academic motivation. Research by Gustiani (2020) showed that the decrease of academic motivation during online learning was because of several reasons, such as isolated feelings, failure in technology, poor time management, lack of intention, poor condition external factor, and high level of amotivation. Furthermore, the frequent and unavoidable experience of internet connection interference made this problem even worse. The students became more passive as the consequence of many problems they faced while attending online classes. Heng and Sol (2020) found the same findings that heavy workload, technology issue (lack of digital competence, lack of knowledge how to use application, incompatible browser, etc), and inadequate supervision from the lecturers are the factors contribute to the decrease of student academic motivation.

Another research conducted by Meşe and Sevilen (2021) showed that online learning brought negative perception because of lack of interaction between students with their teachers and classmates, and also poor of teacher feedback. In line with previous research, Fung, Magdeline, and Kamei (2020) emphasized that the main factors that affect the decrease in students' learning motivation was minimal interaction between lecturers and students. This statement is also in line with Simamora (2020) research that stated external factors as the antecedent of the decrease in academic motivation. This brings Heng and Sol (2020) to a suggestion to keep turn on the camera for both the lecturers and students for the sake of maintaining concentration while listening and doing activities in class. Another research found low self-concept as a factor that affect academic motivation level. Research by Hanesty, Neviyarni, and Karneli (2020) showed that more than 32.81\% participant in moderate category had low self-concept. Hanesty, Neviyarni and Karneli (2020) declared self-concept is the real cause of low academic motivation, indicated more than $32 \%$ of participant in low and very low motivation category in their research. Consistent with previous studies, limited skill in technology and teacher support were the factors contribute to the decrease of academic motivation as mentioned by $34 \%$ and $70 \%$ students in this research, respectively.

Several researches gave some suggestions with the intention to overcome low motivation problem, especially in the online learning due to COVID-19. First, research by Gustiani (2020) showed that the students who are successfully adapt this change was the one 
who had high intrinsic motivation, personal interest, and actively participated in the discussion. Based on the literature review conducted by authors, the lecturers need to improvise the methods and contents for learning. In the interest of providing a more interactive learning process, the lecturers could use medias such as Mentimeter, Kahoot!, Classtime, etc as an innovation in the learning method. Second, findings from Putra (2021) research indicated that learning method innovations could increase all aspect of learning, such as willingness to learn, collecting and completing assignments, learning discipline, stating the ideas from student. The mean of all aspect of learning in this research was increase from $43.3 \%$ in the early to $61.8 \%$ and further increase become $79.4 \%$ at last. Besides innovation in learning method, lecturers need to give significant feedback for their students. Positive feedback will enlarge students' self-confidence and self-efficacy, at the end will improve students' academic skills (Suryatiningsih, Mabaroh, \& Pradikto, 2021). Furthermore, research by Meşe and Sevilen (2021) stated that students respect the lecturers even they get negative feedback rather than get no feedbacks at all. The students admitted that the negative feedback may boost their motivation, even though the got stress and anxiety at the same time (Meşe \& Sevilen, 2021). Korkmaz and Toraman (2020) revealed that the online learning process would be interesting, usefsul, and anticipated by students if the lecturers have adequate digital literacy skills. The principle of online learning process was not as monotonous as the traditional face-to-face class and the students could explore the lecture's material from various sources, for instance youtube, podcast, website, etc.

The decrease in students' academic motivation as reflected in the result of this study was certainly a serious problem that need to prioritize to be solved. COVID-19 has continued to evolve, producing new and more frightening variants, but on the other hand, education is compelled to continue even better though in this difficult time. The student need to adapt with this difficult situation along with the lecturers that should overcome this problem with creating an interesting, useful, and intelligible learning process. The findings of this research provide prior description for government to formulate policies that support education in pursuit of resolving the problems in academic motivation well.

After reading this article, we expect the readers (lecturers and also students) to be able to reflect on their condition and learning process. For this purpose, the authors provided Academic Motivation Scale Bahasa Indonesia - Versi Singkat in the appendix to enable selfassessment for the students, as well as a student evaluation tools for the lecturers. It is a necessity for the students to consider and make an action plan to restore their academic motivation. Additionally, through this research findings, we expect that the lecturers could realize their important role in this situation and plan innovations in order to improve students' engagement in the learning process.

This research had limitation. Although there was a large amount of data, the main limitation of this study is being only a repeated cross-sectional study with subjects which are not $100 \%$ similar. It should be acknowledged that this research cannot fully portray the changes of academic motivation on each of the respondents. Further research with time series longitudinal method is needed in order to give description regarding changes in academic motivation from each participant. In addition, it is also possible to correlate academic motivation and academic achievement during the Learning From Home (LFH) period. It is intended so that the next research will be able to give a more precise and accurate description of the impact of COVID-19 on education, especially higher education in Indonesia.

\section{CONCLUSION}

According to the data collected and analysed in this study, it was known that academic motivation change overtime. Majority of the participant in this research had a high level of 
motivation in before, early, and one year after COVID-19. However, some of students that had high motivation level in before and early COVID-19 shifted to slightly high category after one year of COVID-19. There were many factors that could affect the decrease in academic motivation. One of the findings highlighted in this research was the importance of interaction and collaboration between lecturers and students in learning process. Lecturers have a critical role to give major impact to students' academic life. It is a necessity for the learning environment to remain conducive even though the learning process that is mostly done online.

Therefore, it is with great hope that the policymakers would be able to accommodate every need to maximize the adaptation of both lecturers and students. For instance, a support for the lecturers in the form of training to increase their digital literacy skills in order to elevate and optimized the learning process, especially in delivering materials. On the students' side, mentoring and counselling services could be provided by the faculty and/or university so the students could seek proper help when they started having learning problems as soon as possible without feeling shameful or alienated. All these things are necessary on the grounds that online learning will sooner or later dominate the educational system. The educational process must succeed in providing useful knowledge and skills in order to solve local, national, or even global problems in the future.

\section{REFERENCES}

Adiputra, S., \& Mujiyati, M. (2017). Motivasi dan prestasi belajar siswa di Indonesia: Kajian meta-analisis. Konselor, 6(4), 150-157. https://doi.org/10.24036/02017648171-0-00.

American Educational Research Association, American Psycological Association, and National Council on Measurement in Education. (1999). Standards for educational and psychological testing. Washington DC.

Anas, M., \& Aryani, F. (2014). Motivasi belajar mahasiswa. Jurnal Penelitian Pendidikan INSANI, 16(1), 41-46. https://doi.org/10.26858/ijes.v16i1.3973.

Azwar, Z. (2008). Penyusunan Skala Psikologi. Yogyakarta: Pustaka Pelajar.

Broussard, S. C., \& Garrison, M. E. B. (2004). The relationship between classroom motivation and academic achievement in elementary-school-aged children. Family and Consumer Sciences Research Journal, 33(2), 106-120. https://doi.org/10.1177/1077727X04269 573.

Browning, M. H. E. M., Larson, L. R., Sharaievska, I., Rigolon, A., McAnirlin, O., Mullenbach, L., Cloutier, S., Vu, T.M., Thomsen, J., Reigner, N., Metcalf, E.C., D'Antonio, A., Helbich, M., Bratman, G.N., \& Alvarez, H. O. (2021). Psychological impacts from COVID-19 among university students: Risk factors across seven states in the United States. PloS One, 16(1). https://doi.org/10.1371/journal.pone.0245327.

Coaley, K. (2010). An Introduction to Psychological Assessment and Psychometrics. London: SAGE Publication Ltd.

Cokley, K. (2015). A confirmatory factor analysis of the academic motivation scale with black college students. Measurement and Evaluation in Counseling and Development, 48(2), 124-139. https://doi.org/10.1177/0748175614563316.

Fung, F., Magdeline, N., \& Kamei, R. (2020). How to create engaging online learning amid COVID-19 pandemic: lessons from Singapore. Retrieved from The Conversation website: https://theconversation.com/how-to-create-engaging-online-learning-amidcovid-19-pandemic-lessons-from-singapore-138979.

Gerald, B. (2018). A brief review of independent, dependent and one sample t-test. International Journal of Applied Mathematics and Theoretical Physics, 4(2), 50. https://doi.org/10.11648/j.ijamtp.20180402.13.

Guay, F., Chanal, J., Ratelle, C. F., Marsh, H., Larose, S., \& Boivin, M. (2010). Intrinsic, 
identified, and controlled types of motivation for school subjects in young elementary school children. British Journal of Educational Psychology, 80(4), 711-735. https://doi.org/10.1348/000709910X499084.

Guay, F., Morin, A. J. S., Litalien, D., Valois, P., \& Vallerand, R. J. (2015). Application of exploratory structural equation modeling to evaluate the academic motivation scale. Journal of Experimental Education, 83(1), 51-82. https://doi.org/10.1080/00220973 .2013.876231.

Gustiani, S. (2020). Students ' motivation in online learning during Covid-19 pandemic era : a case study. Holistics Journal, 12(2), 23-40.

Hanesty, E., Neviyarni, N., \& Karneli, Y. (2020). Factors affecting student learning motivation during the Covid-19 pandemic. International Journal of Applied Counseling and Social Sciences, 02(1), 100-107. https://doi.org/10.24036/005404ijaccs.

Hazrati-Viari, A., Rada, A. T., \& Torabi, S. S. (2012). The effect of personality traits on academic performance: The mediating role of academic motivation. Procedia - Social and Behavioral Sciences, 32, 367-371. https://doi.org/10.1016/j.sbspro.2012.01.055.

Heng, K., \& Sol, K. (2020). Online learning during COVID-19: Key challenges and suggestions to enhance effectiveness. Retrieved from Cambodian Education Forum (CEF).

Hensley, L. C. (2014). Reconsidering active procrastination: Relations to motivation and achievement in college anatomy. Learning and Individual Differences, 36, 157-164. https://doi.org/10.1016/j.lindif.2014.10.012.

Kim, G.C. \& Gurvitch, R. (2020). Online education research adopting the community of inquiry framework: a systematic review. Quest, 72(4), 395-409. https://doi.org/ 10.1080/00336297.2020.1761843.

Kim, K.T. (2015). T test as a parametric statistic. Korean Journal of Anesthesiology, 68(6), 540-546. https://doi.org/10.4097/kjae.2015.68.6.540.

Korkmaz, G., \& Toraman, Ç. (2020). Are we ready for the post-COVID-19 Educational practice? An investigation into what educators think as to online learning. International Journal of Technology in Education and Science, 4(4), 293-309. https://doi.org /10.46328/ijtes.v4i4.110.

Malhotra, R., Chan, A., Malhotra, C., \& Stbye, T. (2012). Validity and reliability of the caregiver reaction assessment scale among primary informal caregivers for older persons in Singapore. Aging and Mental Health, 16(8), 1004-1015. https://doi.org/10.1080/13607863.2012.702728.

Meşe, E., \& Sevilen, Ç. (2021). Factors influencing EFL students' motivation in online learning: A qualitative case study. Journal of Educational Technology \& Online Learning, 4(1), 11-22. https://doi.org/10.31681/ jetol.817680.

Natalya, L. (2016). Struktur internal. In I. Siaputra \& L. Natalya (Eds.), Teori dan Praktik Cara Asyik Belajar Pengukuran Psikologis. Fakultas Psikologi Universitas Surabaya.

Natalya, L. (2018). Validation of academic motivation scale: Short Indonesian language version. ANIMA Indonesian Psychological Journal, 34(1), 43-53. https://doi.org /10.24123/aipj.v34i1.2025.

Natalya, L., \& Purwanto, C. (2018). Exploratory and confirmatory factor analysis of the Academic Motivation Scale (AMS)-Bahasa Indonesia. Makara Human Behavior Studies in Asia, 22(1), 29-42. https://doi.org/10.7454/hubs.asia.2130118.

Odriozola-González, P., Planchuelo-Gómez, Á., Irurtia, M. J., \& de Luis-García, R. (2020). Psychological effects of the COVID-19 outbreak and lockdown among students and workers of a Spanish university. Psychiatry Research, 290, 1-8. https://doi.org/10.1016 /j.psychres.2020.113108.

Putra, R. W. P. (2021). Improving the students' motivation in learning english through google 
meet during the online learning. English Learning Innovation, 2(1), 35-42. https://doi.org/10.22219/englie.v2i1.14605.

Ryan, R., \& Deci, E. (2000). Self-determination theory and the facilitation of intrinsic motivation, social development, and well-being. American Psychologist Association, 55(1), 68-78. https://doi.org/10.1037/0003-066X.55.1.68.

Ryan, R., \& Deci, E. (2017). Self-Determination Theory: Basic Psychological Needs in Motivation, Development and Wellness. New York: The Guilford Press.

Sabna, E., \& Muhardi, M. (2016). Penerapan data mining untuk memprediksi prestasi akademik mahasiswa berdasarkan dosen, motivasi, kedisiplinan, ekonomi, dan hasil belajar. Jurnal CoreIT: Jurnal Hasil Penelitian Ilmu Komputer Dan Teknologi Informasi, 2(2), 41-44. https://doi.org/10.24014/coreit.v2i2.2392.

Santrock, J. (2017). Educational Psychology (6th ed). New York: McGraw-Hill Education.

Simamora, R. M. (2020). The challenges of online learning during the COVID-19 pandemic: An essay analysis of performing arts education students. Studies in Learning and Teaching, 1(2), 86-103. https://doi.org/10.46627/silet.v1i2.38.

Slameto. (2015). Belajar dan Faktor-Faktor yang Memengaruhinya. Jakarta: Rineka Cipta.

Suryatiningsih, N., Mabaroh, B., \& Pradikto, S. (2021). The impacts of Covid-19 on the students learning behavior. Universitas Muhammadiyah Gresik Engineering, Social Science, and Health International Conference, 1(1), 48-56.

Tan, C. (2021). The impact of COVID-19 on student motivation, community of inquiry and learning performance. Asian Education and Development Studies, 10(2), 308-321. https://doi.org/10.1108/AEDS-05-2020-0084.

Uno, H. (2014). Teori Motivasi dan Pengukurannya: Analisis di Bidang Pendidikan. Jakarta: Bumi Aksara.

Vallerand, R. J., Pelletier, L. G., Blais, M. R., Briere, N. M., Senecal, C., \& Vallieres, E. F. (1992). The academic motivation scale: a measure of intrinsic, extrinsic, and amotivation in education. Educational and Psychological Measurement, 52(4), 10031017. https://doi.org/10.1177/0013164492052004025.

Wang, C., Pan, R., Wan, X., Tan, Y., Xu, L., Ho, C. S., Ho, R. C., (2020). Immediate psychological responses and associated factors during the initial stage of the 2019 coronavirus disease (COVID-19) epidemic among the general population in China. International Journal of Environmental Research and Public Health, 17, 1-25. doi: 10.3390/ijerph17051729.

Waqar, S, Shafiq, S., \& Hasan, S. (2016). Impact of procrastination and academic motivation on academic self-efficacy among university students. IOSR Journal Of Humanities And Social Science (IOSR-JHSS, 21(6), 7-13. https://doi.org/10.9790/0837-2106040713. 